\title{
JUURNAL.RU
}

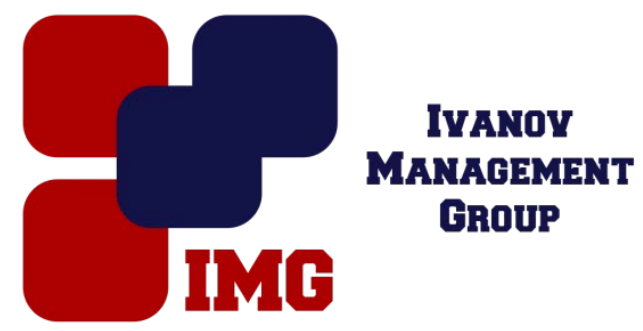

Жукова С.А., Морев М.И. ОГУ Оренбург, Россия

doi: 10.18411/lj-30-11-2016-1-05

idsp 000001:lj-30-11-2016-1-05

\section{Основные направления модернизации транспортной системы России и отдельных городов в целом}

\section{Аннотация}

В данной статье представлены основные методымодернизации и рационализации транспортной системы, которые могут быть применены в большей или меньшей степени для каждого отдельно взятого города России.

Ключевые слова: стремительный рост, модернизация, создание оптимальной инфраструктуры.

В настоящее время стремительный рост движения по автомобильным дорогам и резкое увеличение количества транспортных средств требует внедрения современных, кардинальных методов решения возникающих в связи с этим проблем. Проблемы заключаются в постоянно возникающих пробках на дорогах, частых авариях, нехватке парковочных мест и т.д.

В связи с этим т/сстраны не просто не должна стоять на месте, а развиваться огромными темпами.

Модернизация и развитие т/с включаетв себя целый ряд мероприятий для наиболее комфортного и быстрого сообщения между различными частями города.

1. Начать строительство многоуровневых перекрёстков и развязок. Тем самым снизится процент ДТП, который за 2015 год, по некоторым данным увеличился на 13,2 процента. Отсутствие светофоров на таких перекрёстках, и отсутствие пересечения с автомобильным потоком перпендикулярного направления ведут за собой весьма положительные последствия. Даже без точных подсчётов можно представить насколько уменьшится время пребывания в авто при переезде из одной точки города в другую!

2. В эту же категорию можно отнести увеличение количества как подземных, так и надземных пешеходных переходов. Возможно применение эскалаторов для наиболее удобного перехода граждан.

3. Увеличение комфорта и качества, и уменьшение кол-ва общественного транспорта за счёт увеличения его габаритов и внутреннего пространства. 
Создать все условия для комфортного передвижения людей в таком транспорте. Ввести приоритеты для данного транспорта. Но полностью отказаться от малогабаритного общественного транспорта будет нельзя, так как некоторые улицы, в основном в центре города, не позволят свободно перемещаться крупногабаритному транспорту.

Создание парковочной инфраструктуры.

Автомобилей становится все больше, а мест для парковки больше не становится - темпы решения проблемы в несколько раз отстают от скорости прироста транспорта у горожан.

Варианты решения:

- строительство подземных парковок;

- строительство многоярусных парковок;

- строительство перехватывающих парковок на въезде в город или его центральную часть;

- запрет или ограничение въезда в центр города на личном транспорте (кроме жителей центральных районов);

- увеличение штрафов за нарушение правил парковки;

- создание экологических парковок. Это самый перспективный вариант решения парковочной проблемы - о нем хотелось бы сказать несколько слов.

1) Внедрение реверсивного движения на наиболее проблемные в отношении пробок улицы города.

2) Развитие параллельных магистралей.

3) Это позволит убрать часть нагрузки с прилегающих улиц.

4) Проектирование ж/д. сетей, которые будут охватывать все населённые пункты по области и сообщать их с нашим городом.

5) Расширение проезжей части там, где это возможно.

6) И наконец последнее, и возможно самое главное - это улучшение качества дорожного полотна, своевременный ремонт и качественное обслуживание проезжей части в любое время года.

Ведь ямы в наше время - это бич настоящего времени, в особенности весною. И именно весною, наибольший процент ДТП происходит из-за выбоин в дорожном полотне, не говоря уже о погнутых дисках и пробитых покрышках. А аварии зачастую являются причиной заторов и пробок, которые сильно затрудняют движение. 


\section{Литература}

1. Бабков В.Ф., Андреев О.В., «Проектирование автомобильных дорог в 2-х частях» Ч.1-И учебник для вузов- Издание 2-е, переработанное и дополненное-,М,: Транспорт, 1987-368 с.

2. Карташкова Л.М., Штерн В.О. Проектирование автомобильных дорог: учебное пособие. Оренбург: ИНК ГОУ ОГУ, 2006. - 136 с.

3. Васильев, А.П. Справочная энциклопедия дорожника/ А.П. Васильев. -М.: Ви АртПлюс, 2005. - 647c. 